\title{
Vulnerable Subjects
}

National Cancer Institute

\section{Source}

National Cancer Institute. Vulnerable Subjects. NCI Thesaurus. Code C142747.

Volunteers for clinical studies who may be unreasonably persuaded to participate by perceived benefits, or fear of punishment by superiors. 